\title{
Georg Simmel and Pragmatism
}

\author{
Martin Kusch
}

\section{(2) OpenEdition}

\section{Journals}

Electronic version

URL: http://journals.openedition.org/ejpap/1490

DOI: 10.4000/ejpap.1490

ISSN: 2036-4091

\section{Publisher}

Associazione Pragma

Electronic reference

Martin Kusch, "Georg Simmel and Pragmatism », European Journal of Pragmatism and American Philosophy [Online], XI-1 | 2019, Online since 19 July 2019, connection on 21 December 2020. URL: http://journals.openedition.org/ejpap/1490 ; DOI : https://doi.org/10.4000/ejpap.1490

This text was automatically generated on 21 December 2020.

\section{(c) (i) $\odot$

Author retains copyright and grants the European Journal of Pragmatism and American Philosophy right of first publication with the work simultaneously licensed under a Creative Commons AttributionNonCommercial-NoDerivatives 4.0 International License. 


\title{
Georg Simmel and Pragmatism
}

\author{
Martin Kusch
}

\section{AUTHOR'S NOTE}

Work on this paper was made possible by ERC Advanced Grant Project "The Emergence of Relativism" (\#339382).

\section{§1. Introduction}

1 Georg Simmel's name does not appear in book-size accounts of the pragmatist tradition. But the latter does regularly feature in monographs on Simmel's intellectual development. Simmel-scholars seem to agree that he was - at least at one stage of his life - close to pragmatism. Horst Helle even declares Simmel to be the "inspiration" behind this whole intellectual movement (1988: 60). Wilfried Geßner disagrees, but he too diagnoses a "continuous proximity" (2003: 64). As will become clear in what follows, I am closer to Geßner than to Helle.

Many of Simmel's contemporaries also diagnosed a proximity to pragmatism. Of his German and Austrian colleagues, Leonard Nelson discussed Simmel's pragmatist tendencies in correspondence with his father in 1908, right after the Heidelberg Philosophie Kongress in which pragmatism featured prominently (Simmel 2008: 660-1). Around 1905 Hugo Münsterberg encouraged William James to read Simmel; in so doing Münsterberg emphasized Simmel's pragmatist leanings (Perry 1935: 470). Wilhelm Jerusalem (in 1913) praised Simmel's Philosophie des Geldes (1989 [1900]) for its pragmatist theory of truth. And Max Frischeisen-Köhler argued that Simmel anticipated central themes of American pragmatism (1920: 15).

Even some American pragmatists showed an interest in Simmel. In reply to Münsterberg, James (in 1905) wrote that he had read Simmel's "original pragmatistic article (which seemed to me rather crude, though essentially correct) [...]" (Perry 1935: 470). James referred to Simmel also in his published writings. In The Meaning of Truth James remarks 
that in "Germany the name of Simmel offers itself as that of a humanist of the most radical sort" (1909: 28). Simmel fared well also amongst U.S. sociologists. Albion Small, the head of the sociology department in Chicago between 1892-1924, published no less than 15 translations of Simmel's texts in the American Journal of Sociology. And George Herbert Mead published a longish and highly positive review of Philosophie des Geldes, concluding that it "demonstrates [...] the value of approaching economic science from the philosophic standpoint" (1901: 619). Simmel's influence on Mead has been noted by several scholars (e.g. Prus 1996: 144).

What did Simmel himself think about his relationship to pragmatism? This question is not easy to answer since at different times Simmel gave different answers. I shall look at his published record below, but in order to give an initial sense of his wavering, the following two comments will serve. Neither was published during Simmel's life. In 1908 Heinrich Nelson reported to his son Leonard the following conversation with Simmel:

[...] he remarked [...] that it is strange that everyone counts him amongst the pragmatists just because, many years ago, he wrote something en passant which sounds vaguely similar; whereas his whole general tendency is absolutely different [...]. (Simmel 2008: 660-1)

5 And yet, in 1916 Simmel wrote a one-page document in which he "took stock" of "the original central motifs" he thought himself to have contributed to the "Geistesentwicklung ." And here his early work on truth did get a special mention:

[...] the concept of truth, developed out of the context of life (an idea which later, in a crass and crooked way, and independently of my hard-to-find paper, was developed under the title "pragmatism") [...]. (Simmel 2016: 71)

\section{§2. "The Relationship between the Theory of Selection and Epistemology" (1885)}

6 I now turn to the published sources. The most important piece of evidence is the early 1885-paper, the paper which James read and which lead to the perception of Simmel as a pragmatist.

7 Simmel begins by explaining the "received view" he wishes to dislodge. Both the received view and Simmel himself accept that cognition is the result of "the practical necessities to preserve [...] life" (1885: 70). But the received view adds an important two-pronged "assumption": to wit, that there is a set of "objective truths," independent of all cognizers; and that different cognizers, with different needs and under different selection pressures, grasp different subsets of these objective truths. We might call this the "spotlight" model: the needs of the species determine the direction of the cognitive spotlight that brings truths into view. Moreover, for the received view, truth means "an objective mirroring of the world." And finally, the "goal of mental selection" is that thought "parallels" "objectivity," thereby avoiding clashes with reality (1885: 71).

What Simmel finds problematic about the received view is its dualism of "practical lifeconstituting needs" on the one hand, and the "objectively cognizable world" on the other hand. Simmel wants to find a "common root at a deeper level." His proposal is that: "[...] there is no theoretically valid 'truth' on the basis of which we act in ways advantageous to us [...] [Rather] we call those beliefs 'true' that [...] [are] the basis for advantageous, lifesupporting actions." (1885: 72). To make sense of this passage, it is important to keep in mind that when Simmel talks of "truth" being "theoretically valid," he refers to the ideas 
of truth as correspondence, coherence or provability. In the quoted passage Simmel thus wants to introduce a concept of truth that is "practical," and thereby independent of the ideas of correspondence, coherence and provability (1885: 72).

9 As Simmel has it, there is one important "prejudice" that stands in the way of his proposal: this is the prejudice according to which "cause and effect must have the same form [eine morphologische Gleichheit]" (1885: 72). What he has in mind is the idea that a mental effect must have a mental cause, or more specifically, that a conscious mental effect must have a conscious mental cause. The version of the prejudice most important in the present context is this. Assume one of our actions triggers the conscious state of feeling satisfied with the way the world is. Call this way "p." According to the prejudice, such conscious state must have among its "immediate" causes other conscious states of a certain kind. These other conscious states too are "satisfactory" or "successful," namely satisfactory and successful insofar as they accurately represent the state of the world $p$ which the subject desired, and that was brought about by the action. In other words, the state of satisfaction and the action-guiding representation must have the same propositional content $\mathrm{p}$.

According to Simmel, the assumption of "morphological identity" is a mistake. Conscious volitions and "plans" (qua causes) lead to actions (qua effects) via sequences of neural and muscular causal processes, none of which typically is conscious. A specific volition and representation can cause an action, which in turn causes a feeling of satisfaction, without that this representation endures and guides in a homogeneous and continuous conscious mental realm. Instead the combination of volition and representation triggers the propagation of a "force" across neural and muscular states, a force that eventually results in the satisfying action. Simmel writes: "[...] a force that via the most varied transformations in the mental, bodily and inorganic world eventually results in a subjectively satisfying and objectively advantageous result." (1885: 73). Simmel compares this process to the transmission of words by means of the telegraph. The physical processes in the wire bear no resemblance to the words that are written down in response to these physical processes at the destination. Moreover, the fact that an action based on a mental representation is satisfying does not "decide in advance" what the relationship between representation and the facts must be.

11 It remains for Simmel to explain how the mechanism of selection functions under the conditions of his proposal, or his "New Idea" (as I shall call it subsequently). The answer is this: : "[...] among the countless beliefs that appear in consciousness there are some whose effects prove to be useful for action and life-supporting for the subject. These beliefs get picked out by the usual processes of selection, and taken as a whole they form the 'true' world of beliefs." (1885: 73). By calling these useful beliefs "true," we give them a special "dignity." Or as Simmel puts it later in the paper: "For an animal that belief is true which leads the animal to behave in its circumstances in the most advantageous way; and this because the demand for this behaviour has formed the very organs that shape the animal's beliefs." (1885: 75).

12 The idea seems clear enough. Still, let me repeat it in my own words. Some types of beliefs lead to actions that increase fitness. And the cognitive faculties which produce such types beliefs are therefore selected by evolution. Humans do not generally understand this mechanism. But they notice that certain (types of) beliefs in the ancestry of their satisfaction-triggering actions are important. And they therefore dignify these beliefs with the label "truth." 
Earlier I quoted Simmel as saying "[...] there is no theoretically valid 'truth'." Nevertheless, as his argument progresses, Simmel comes to soften this stance: according to this more moderate view, the "practical" conception of truth is primary with respect to theoretical truth. While Simmel thinks that - after Kant - truth as correspondence is out of the question, he still is willing to leave room for truth as coherence or provability. The primacy of practical truth lies in the fact that the truth of our criteria and axioms can ultimately only be practical (1885: 74).

Simmel is well aware that his theory has relativistic consequences. Consider non-human animals and their sensory beliefs. Since they have different needs from us, they must also have perceptual systems very unlike ours. Note here that Simmel stresses the distinction between "true" and "false" beliefs also in the case of animals. After all, animals too have "misperceptions," and they too make mistakes they later correct. And yet, when animals correct a mistake, they do not thereby reach "absolute truth." At best they reach a "normal belief" for their species. The same is true of humans (1885: 75).

Finally, and in conclusion, Simmel stresses that the difficulty of the New Idea is analogous to the difficulty of Kant's theory of space ...

The process of intuition [Anschauungsprozess], following its immanent laws - the scientific expression of which are mathematical sentences - creates what we call "space." In similar fashion, our thinking, in accordance with the principle of usefulness, creates certain norms of its behaviour. In and through these norms comes about what we call "truth"; and the abstract formulation of these norms are the logical laws. (1885: 77)

Here I have not got enough space to explore Simmel's historical debts to other authors before him - a detailed analysis would have to mention at least Darwin, Spencer, Windelband, Lange and especially von Helmholtz. ${ }^{1}$ At this point it suffices to stress that Simmel did not need to read the early American pragmatists to arrive at his New Idea. He had enough other authors, closer to home, from whom he could pick up the building blocks for his position. von Helmholtz is particularly important. Simmel's text contains numerous allusions to the famous $\$ 26$ of von Helmholtz's Handbuch der physiologischen Optik (1867). In this context it is interesting to remember that Simmel's first attempt (in 1880) to gain a doctorate in philosophy - with a thesis on Darwin - failed because of von Helmholtz's criticism. von Helmholtz pointed out that the young Simmel lacked sufficient knowledge of physiology and biology (Simmel 2016: 182-3). It may well be that Simmel's 1885-paper was an attempt to show von Helmholtz that Simmel had learnt his lesson.

In many ways Simmel's paper reads like a further development of von Helmholtz's claim that "the only sense in which our sensory presentations can be said to be true, is practical " (1867: 443). Simmel also picks up on the idea that sensations are mere "signs" or "symbols," not "copies" of events in the external world. And the discussion of Kant on space at the end of Simmel's paper recalls von Helmholtz's discussion of "axioms" of geometry and spatial intuition. Not to forget that von Helmholtz also uses the "telegraph" analogy (1867: \$26). I think this evidence speaks for itself. It is also worth pointing out that von Helmholtz too was sometimes regarded as a pragmatist. For instance, in the Heidelberg philosophy congress of 1908 - in which pragmatism figured prominently - Gregorius B. Itelson, a Ukrainian Privatgelehrter living in Berlin, claimed that von Helmholtz's $\$ 26$ very much anticipated the "formula of pragmatism," at least for sensations (Elsenhans 1909: 91). 


\section{§3. Philosophy of Money (1900)}

18 The next obvious question is: what happened to Simmel's New Idea in his later work? Did he quickly leave it behind, as he suggested to Heinrich Nelson in 1908? I think not. It seems to me that Simmel was not entirely honest when he talked to Nelson.

19 In Philosophie des Geldes (1989 [1900]) the New Idea re-appears, in an abridged form, as one argument in defence of relativism. But there is now an important new twist in that Simmel introduces the idea of "normative stability": for each animal species there is a "principally fixed" set of truths constituted by the species' needs. Thus, given human needs, Newton's "Law of Universal Gravitation" would be true even if humans had never formulated it (1989 [1900]: 102). This move seems to be Simmel's quick way of answering Husserl's and the Neo-Kantians' objections to naturalistic views in logic and epistemology.

\section{\$4. Kant (1904), Goethe (1913), and "The Conflict of Modern Culture" (1918a)}

In his Kant-book of 1904 Simmel criticizes the Königsberg philosopher for overlooking what Simmel claims pragmatism has correctly recognized: to wit, that radical Erkenntniskritik must locate knowledge in the "total context of life" (Simmel 1997 [1904]: 50). Unfortunately, Simmel does not go into any detail.

21 Jerusalem in 1913 objected to the fact that in his Goethe-study (of 1913) Simmel had called pragmatism "crude." But this seems to be a misreading on Jerusalem's part: in "roher Pragmatismus" the attribute is used in a restrictive sense, that is, there are also forms of pragmatism that are not "roh" - Simmel's own pragmatism for example (Simmel 2003 [1913]: 33).

22 "Der Konflikt der modernen Kultur" (1918a) calls "American" pragmatism "the most superficial and limiting version" (1999 [1918a]: 196). Simmel immediately goes on however to present his own version as an adequate expression of the Zeitgeist (1999 [1918a]: 198). That the idea appears so prominently even in 1918 is a further indication that Simmel never gave it up. The evidence for this thesis is even stronger in Lebensanschauung.

\section{§5. The Perspective of Life (1918b)}

23 This book is the most important source for understanding what Simmel gave up, and what he kept, of the New Idea of 1885 even in his last writings. In a nutshell, and put anachronistically, Simmel now insists on science, religion and art as "constructed niches": as such they are "in the last instance" dependent upon biological evolution. But this dependence notwithstanding, they also have a considerable degree of independence.

Incidentally, here too Simmel is influenced by other authors. Already the word " Lebensanschauung" is a clear allusion to Rudolf Eucken who used the term in a book title already in 1890 (Eucken 1890). Simmel reviewed Eucken's book positively, writing that "I do not know any living philosopher whom I regard as a deeper thinker" (Simmel 1999 
[1918b]: 273). Be this as it may, Eucken's distinction between "biological" and "noological" evolution bears more than a superficial resemblance to Simmel's distinction between biological and the "ideocentric" evolution. That said, finding a way of reconciling biology (or organism) with the social and human sciences (or culture) was a central problem for everyone at the time: in Europe and the US. And of course it still is a challenge a hundred years later.

The New Idea of 1885 remains important in Lebensanschauung even though Simmel now restricts its scope. He makes full use of it when he offers an evolutionary-epistemological argument against scepticism:

(1) If our (human) cognitive system did not produce many true beliefs, our species would have died out long ago.

(2) Our species has not died out long ago.

Ergo:

(3) The human cognitive system does produce many true beliefs. (Simmel 1999 [

1918b]: 257)

Unfortunately, Simmel does not spell out how truth is here to be taken. Normally such evolutionary arguments tend to presuppose truth in a realist, correspondence sense. But slotting in Simmel's truth-as-species-specific useful cause of fitness-increasing actions does also works in this context.

Simmel regards scientific research as no more than a "wave" or "scene" of biological life. And he alludes to von Helmholtz' "practical truth" of sensations in passing (1999 [1918b]: 258). Moreover, in line with the 1885-position, he writes: “[...] we call those intellectual contents 'true' that have proven their mettle in the way they further the life [of the species or our social community]." Simmel also still maintains that the practical needs of our "form of life" have led to a certain form of cognition. It builds "a world for our practical life." Simmel still accepts the relativism that follows (1999 [1918b]: 259-60).

The central new twist comes when Simmel points out that our cognitive apparatus has produced in us awareness of certain general ideas, ideas such as "causation, inductive and deductive inference, or systematic order [...]." These ideas have become "ideal [...] criteria" for further knowledge-gathering: "In barely noticeable transitions they have - in certain contexts - replaced the practical unconscious criterion of being useful in the evolutionary struggle for survival." (1999 [1918b]: 283). The crucial change is one of attitude or intention: from the "biological" to the "ideocentric." The latter term sounds like a neologism to answer the pragmatists Jerusalem and Perry who spoke of pragmatism as "biocentrism." The crucial change in attitude amounts to an "axial rotation": "first humans gather knowledge in order to live, then there are humans who live in order to gain knowledge." (1999 [1918b]: 261). This means that the original connections between beliefs are dissolved and that beliefs are re-ordered according to the "intrinsic values" of science (1999 [1918b]: 262).

Simmel concludes his discussion with three provisos. First, the results of science can be "reinserted" into the biological-evolutionary context (1999 [1918b]: 262). Second, science as a whole can only be justified via the evolutionary argument from survival summarized above (1999 [1918b]: 264). And third: “[...] many contents, considered in isolation, look the same in the biological predecessor of science, and in science itself." (1999 [1918b]: 266). Let me also add a proviso of my own. Even as concerns the "ideocentric" element there is continuity rather than a radical break between 1885 and 1918. After all, already in the 
1885 paper Simmel allowed for theoretical truth, truth that builds on axioms and standards which in turn need to be understood in an evolutionary light.

\section{§6. Simmel and Peirce}

In §§2-5 above I have assembled the core elements of one of Simmel's central lines of philosophizing, to wit, the line of argument that several interpreters have taken to be pragmatist in character. In the remainder of this paper I want to explore the issue of Simmel's pragmatism in a different way: I shall compare Simmel's New Idea of 1885 with signature views of the three main "classical American pragmatists," Charles Sanders Peirce, William James and John Dewey. This seems to me of interest despite the fact that Simmel did not read these authors, and that in turn they too were largely unfamiliar with his work. I here wish to explore similarities and differences in positions, not influences.

Starting with Peirce, his best-known thoughts on truth are of course contained in his paper "How to Make Our Ideas Clear" (1878): "All the followers of science are fully persuaded that the processes of investigation, if only pushed far enough, will give one certain solution to every question to which they can be applied. [...] The opinion which is fated to be ultimately agreed to by all who investigate, is what we mean by the truth." (1986 [1878]: 273). In a footnote on the same page, Peirce explains that "fated to be ultimately agreed" means "sure to come true, and can nohow be avoided." The reference to what will invariably happen - provided investigation is not prematurely terminated sounds like a prediction concerning the future of science, that is, rings of a philosophy of history (of science). This highly ambitious overtone may well be the reason why, in later writings, Peirce modifies his position. Rather than appeal to fate he ties truth to a counterfactual scenario: "Truth is that concordance of an abstract statement with the ideal limit towards which endless investigation would tend to bring scientific belief." (1935 [1902]: 565). And in 1908 Peirce follows James in linking truth to "satisfaction": "If Truth consists of satisfaction, it cannot be any actual satisfaction, but must be the satisfaction that would ultimately be found if the inquiry were pushed to its ultimate and indefeasible issue." (1998 [1908]: 449). Of course, James would not have situated the relevant satisfaction so far into the future.

Several aspects of these passages are worth highlighting: truth is characterized counterfactually in terms of an ideal limit; truth is linked to scientific inquiry; and truth is something that is at least approximated in the progress of science. This suggests that for Peirce true, or approximately true, beliefs are those that scientific inquiry can build on (Capps 2019).

33 Finally, Peirce is critical of the correspondence theory of truth. A central reason is that this account of truth fails to refer to processes of inquiry, and central amongst them processes of believing and doubting: "If by truth and falsity you mean something not definable in terms of doubt and belief in any way, then you are talking of entities of whose existence you can know nothing, and which Ockham's razor would clean shave off." (1998 [1906]: 336).

How do Peirce's thoughts on truth relate to Simmel's New Idea? Clearly, the differences are more salient than the similarities. To begin with, whereas Peirce is particularly interested in characterizing truth in the context of scientific inquiry, Simmel's account of truth is first and foremost concerned with those beliefs and needs that all (or most) 
members of a given species regard as instrumental for satisfying their (basic) needs. Moreover, when Simmel briefly addresses truth in the context of science, he is ready to background his "practical" conception of truth in favour of the more traditional "theoretical" conceptions of truth as coherence or truth as provability. This does not mean that Simmel gives up on practical truth - it remains the ultimate backdrop for science, too - but he does not think that practical truth is sufficient for making sense of what scientific inquiry is after.

It is also striking that, other than Simmel, Peirce situates neither individual truths nor the concept of truth in an evolutionary context. More generally, Darwin's or Lamarck's biological theories of evolution do not figure centrally in Peirce at all (Burks 1997). Peirce's most extensive discussion of biological evolution occurs in the 1893 paper "Evolutionary Love." In this text Peirce contrasts Darwinian "evolution by chance" (i.e. "tychastic evolution") with Nägeli's, Kölliker's and Waismann's "evolution by mechanical necessity" (i.e. "anancastic evolution") and "the Gospel's" "evolution by creative love" (i.e. "agapistic evolution"). Peirce laments the fact that in contemporary culture a Darwinian "Gospel of Greed" has managed to all but silence the "Gospel of Christ" with its key message "that progress comes from every individual merging his individuality in sympathy with his neighbors" (1992 [1893]: 357-62). All this would have sounded very foreign to Simmel and is clearly incompatible with his outspoken naturalism.

Simmel differs from Peirce also in how he conceptualizes the relationship between satisfaction and truth. For Peirce the relevant satisfaction is that "which would ultimately be found if the inquiry were pushed to its ultimate and indefeasible issue." For Simmel the pertinent satisfaction is located in actual history, that is, the past and present of a given species.

Prima facie Simmel and Peirce seem closer to one another when the German philosopher writes that the needs of each species determine a "principally fixed" set of truths accessible to that species. Obviously, Simmel does not think that humanity can discover the whole set in anything but a very long, perhaps even endless, process of inquiry. But this is where the similarity with Peirce ends: Simmel does not define truth as what the human species will discover in the future. The humanly accessible truths are determined by evolutionary history in the past and present.

Finally, Simmel and Peirce differ even in their reasons for rejecting the correspondence theory of truth. For Peirce, what makes this account of truth problematic is that it detached the definition of truth from the processes of inquiry. Simmel instead is worried that the theory of correspondence is based upon an untenable dualism of mind and world.

\section{§7. Simmel and James}

Above I quoted the 1905-letter in which James calls Simmel's "original pragmatistic article [Simmel 1885] [...] rather crude, though essentially correct" (Perry 1935: 470). I also noted that James referred to Simmel in The Meaning of Truth (1909) as "a humanist of the most radical sort." To this we can now add that James lists Simmel alongside other allegedly important humanists such as Dewey, Schiller, Bergson, Poincare, Mach, Hertz and Ostwald (1909: 28). James explains that humanists conceive of "the more 'true' as the more 'satisfactory' (Dewey's term)" and "renounce rectilinear arguments and ancient 
ideals of rigor and finality." Calling this "spirit of humanism" a "temper of renunciation" James adds that "satisfatoriness has to be measured by a multitude of standards" and that a decision on what is the most satisfactory path in a given situation must be based upon a provisional weighing up of "pluses and minuses." James stresses that recognizing this provisional and fallible nature of our judgements involves "a real change of heart, a break with absolutistic hopes" and the adoption of an "inductive view of the conditions of belief" (1909: 25). Moreover, "the humanistic state of mind" is shaped by the "suspicion" that what makes one scientific "formula" better than another is not "its literal 'objectivity" but its "usefulness, its 'elegance' or its congruity with our residual beliefs" (1909: 26, 718). As far as truth is concerned humanists conceive of it to mean "[...] everywhere, not duplication, but addition; not the constructing of inner copies of already complete realities, but rather the collaborating with realities so as to bring about a clearer result" (1909: 28).

These brief 1909 comments on truth follow of course on from James' discussions in his Pragmatism: A New Name for Some Old Ways of Thinking (of 1907). This book contains many of the passages for which James' account of truth is famous (or notorious). For instance, James write that a true idea is "one [...] upon which we can ride, [...] that will carry us prosperously from any one part of our experience to any other part, linking things satisfactorily, working securely, simplifying, saving labor; [...]. This is the 'instrumental' view of truth [...]." (1907: 461). Moreover, "the true" is "only the expedient in the way of our thinking, [...]" and the "absolutely' true, meaning what no farther experience will ever alter, is that ideal vanishing-point towards which we imagine that all our temporary truths will some day converge" (1907: 1571). A few pages earlier, James links "truth" to verification, commenting that truth... "happens to an idea. It becomes true, is made true by events. Its verity is in fact an event, a process: the process namely of its verifying itself, its veri-fication." (1907: 1409-16, 1537).

41 Finally, just like Peirce, so also James rejects traditional versions of the correspondence theory of truth. The version of the correspondence theory James rejects postulates - in an abstract fashion - a relationship of agreement or fit between a bit of the world and a human belief. The version James accepts is formulated in terms of verification and satisfaction:

[...] the pragmatist [...] asks what such "agreement" may mean in detail. He finds first that the ideas must point to or lead towards that reality and no other, and then that the pointings and leadings must yield satisfaction as their result. [...] The "satisfaction," [...] is assumed to consist of such satisfactions (in the plural) as concretely existing men actually do find in their beliefs. (1909: 43)

Re-enter Simmel. As we saw above, James was aware at least of Simmel's 1885-paper and he was willing to classify Simmel as a pragmatist and humanist. Alas, Simmel did not return the favour. There are only two perfunctory references to James' psychology in Simmel's oeuvre (2004: 455; 2012: 741) and there is no sign of Simmel ever having made a careful study of James' writings on pragmatism.

Still, it is possible to discern some striking similarities between the two men's views on truth. It is especially noteworthy that both link truth to satisfaction and utility. Indeed, it is easy to imagine that Simmel might have referred to his position as something of an "instrumental view of truth" or that he might have endorsed the metaphorical sentiment that a truth is "any idea upon which we can ride." No doubt the card-carrying relativist Simmel could also have agreed with James' animus against "absolutistic hopes" for our 
knowledge, or against claims to "literal objectivity." After all, such locutions are easily read as referring to the possibility of transcending the biological limits of our evolutionary history, and to seeing the world from something like a "view from nowhere." Not to forget that James and Simmel are united in their opposition to received forms of the correspondence theory of truth. And yet, for all these intriguing similarities, the differences between Simmel and James are profound all the same.

First, when Simmel speaks of certain beliefs being useful, it is clear that the relevant subject is the human species. This is because Simmel is concerned to bring the theory of evolution to bear on epistemology, knowledge and truth. In James' writings, it remains unclear what the relevant subject is supposed to be: the species, the culture, the group, or the individual. To be sure, James speak of "we" or "us": but this talk can be interpreted in precisely these different ways. James' vagueness on this score is all the more astonishing not only because James was aware of Simmel's (or Dewey's) work, but also because, in his Principles of Psychology, James discusses a wide range of evolutionary theories (Darwin, Lamarck, Spencer, Romanes), and sides with Darwin. In so doing he insists that human cognitive faculties are the product of biological (rather than cultural) evolution (James 1918: Ch. 28).

Second, it is doubtful that Simmel would have been comfortable with being lumped together with James, Schiller, Dewey, Bergson, Poincare, Mach, Hertz or Ostwald under the label "humanists" or "pragmatists." Simmel thought highly of Bergson (Simmel 2014) and respected Mach (2008: 166) but he did not signal any commonalities with the others, and certainly did not regard himself as part of the pragmatist or humanist movement.

Third, while Simmel would have agreed with James' unease about "absolutist hopes," at least in 1885 there is no sign of him accepting the idea of "the 'absolutely' true" as that "towards which we imagine that all our temporary truth will some day converge" (James 1907: 1571). For the Simmel of 1885 the latter idea would have been of a piece with the "absolutist hopes" James himself was denouncing. Things are less clear in the Philosophy of Money when Simmel speaks of the set of truths constituted by the needs of the species. At least if these needs are taken to be constant - and if the stage of evolution is held fixed talk of a definite set of truths upon which science might converge, does seem to make sense.

Fourth and finally, James' and Simmel's criticisms of the correspondence theory of truth are directed differently. James tries to rescue what he regards as the plausible core of the "correspondence platitude." That is to say, he seeks to show that a combination of the ideas of verification and satisfaction allows one to capture what is adequate about the concept of correspondence. Simmel's unease is more fundamental: he regards the theory of correspondence to be invariably tried to views that we need to give up. The view that seems most problematic is a dualism of facts and beliefs. This is why, even in Simmel's realm of "theoretical truth," the theory of correspondence does not appear.

\section{§8. Simmel and Dewey}

There is no mention of Dewey anywhere in Simmel's published or unpublished writings, and only one perfunctory reference to one of Simmel's papers (on secrecy) in Dewey (1909: 18335). Nevertheless, of the three classical American pragmatists, Dewey is 
intellectually closest to Simmel's New Idea of 1885. In making this claim, I am not thinking of Dewey's direct comments on truth.

The early Dewey's theory of truth builds on familiar themes from Peirce and James (Capps 2019). He follows Peirce in linking truth to scientific inquiry and he takes his lead from James in characterizing truth as an idea verified by past inquiry. He does not adopt the Peircean thought that truth is "the ideal limit towards which endless investigation would tend to bring scientific belief" (1902: 565). As Dewey puts it in 1911: "From the standpoint of scientific inquiry, truth indicates not just accepted beliefs, but beliefs accepted in virtue of a certain method. [...] To science, truth denotes verified beliefs, propositions that have emerged from a certain procedure of inquiry and testing." (2008 [1911]: 28). The later Dewey develops a more original position in maintaining that the received terms "truth" and "knowledge" are so overloaded with intellectual baggage that they should be replaced with an altogether new terminology. Here the central new term is "warranted assertibility" (2008 [1911]: 15-6).

Like Peirce and James, and throughout his oeuvre, Dewey is willing to accept the correspondence theory only if it is radically reformulated: not as an ideal relationship between a proposition and a state of affairs, but as an interaction of sorts: "Our definition of truth [...] uses correspondence as a mark of a meaning or proposition in exactly the same sense in which it is used everywhere else [...] as the parts of a machine correspond." (2008 [1911]: 45). This motif is kept also in Dewey's later writings: "My own view takes correspondence in the operational sense [...] of answering, [...] as, in short, a solution answers the requirements of a problem." (1941: 178). Or formulated more generally, and in response to Herbert Spencer's thought that life is to be defined as a "correspondence of an inner with an outer order":

[...] the genuine correspondence of life and mind with nature is like the correspondence of two persons who "correspond" in order to learn each one of the acts, ideas and intents of the other one, in such ways as to modify one's own intents, ideas and acts, and to substitute partaking in a common and inclusive situation for separate and independent performances. (1925: 283)

51 The context of this last quote is a discussion of life, cognition and evolution and it is here that Dewey and Simmel are intellectually very close to each other. Like the Simmel of 1885 , so also Dewey is adamant that the theory of evolution in general, and Darwin's Origin of Species must become the central resource of philosophy: "Doubtless the greatest dissolvent in contemporary thought of old questions, the greatest precipitant of new methods, new intentions, new problems, is the one effected by the scientific revolution that found its climax in the 'Origin of Species'." (1997 [1909]: 19). Still, there are both commonalities and differences in Dewey's and Simmel's uses of evolutionary theory. I shall now give examples of both categories.

One important commonality is the goal of overcoming dualisms of various kinds, and especially the dualism of mind and world. As we saw above, the Simmel of 1885 is particularly keen to close the gap between the organism's needs and what the organism given its cognitive faculties - comes to construct as the objective world: True representations for an organism A are those representations that are salient for A as causes of successful attempts to satisfy one of A's needs. Dewey does not formulate his anti-dualism in quite this way but he comes close. For instance, he often denies there to be any "mystery" about the mind's ability to grasp worldly structures: 
[...] traditional theories have separated life from nature, mind from organic life, and thereby created mysteries. [...] Since both the inanimate and the human environment are involved in the functions of life, it is inevitable, if these functions evolve to the point of thinking and if thinking is naturally serial with biological functions, that it will have as the material of thought, even of its erratic imaginings, the events and connections of this environment. And if the animal succeeds in putting to use any of its thinkings as means of sustaining its functions, those thoughts will have the characters that define knowledge. (1925: 278-9) sustain its functions, then Dewey's position is almost identical with Simmel's. Be this as it may, note that elsewhere Dewey seeks to overcome the dualism of organism and environment in the following way:

[...] the distinction [between organism and environment] is a practical and temporal one, arising out of a state of tension in which the organism at a given time, in a given phase of life-activity, is set over against the environment as it then and there exists. There is, of course, a natural world that exists independently of the organism, but this world is environment only as it enters directly and indirectly into life-functions. (1938: 33)

mel lacks an account of environment-organism interaction. Dewey goes further than Simmel also in insisting that evolution is never "over": "Of human organisms it is especially true that activities carried on for satisfying needs so change the environment that new needs arise which demand still further change in the activities of the organism by which they are satisfied: and so on in a potentially endless chain." (1938: 28). This emphasis on the "endless chain" obviously puts pressure on Simmel's talk of "normative stability," that is, the idea that for each animal species there is a "principally fixed" set of truths constituted by the species' needs. Surely, if the species constantly changes and mutates, there is no such stability.

There is an interesting tension between Dewey and Simmel also concerning the latter's attempt to theorize the differences between biological and ideocentric evolution. The crucial change from the former to the latter Simmel calls an "axial rotation": "first humans gather knowledge in order to live, then there are humans who live in order to gain knowledge." (Simmel 1999 [1918b]: 245, and 261). Intriguingly enough, Dewey criticizes a very similar idea in Thomas Henry Huxley. Huxley distinguished between "cosmic" and "ethical" evolutions. Dewey summarises the distinction as follows: "The rule of the cosmic process is struggle and strife. The rule of the ethical process is sympathy and co-operation. The end of the cosmic process is survival of the fittest: that of the ethical, the fitting of as many as possible to survive. [...] The two processes are not only incompatible but even opposite to each other." (1972 [1898]: 36). Dewey rejects the suggestion of a fundamental conflict between "the natural process and the ethical" and by implication talk of "axial rotations" in evolution:

If we personify Nature, we may say that the influences of education and social approval and disapproval in modifying the behavior of the agent, mark simply the discovery on the part of Nature of a shorter and more economical form of selection than she had previously known. (1972 [1898]: 50)

\section{§9. Conclusion: Was Simmel a Pragmatist?}

Since the argument of this paper has been long and complex, it is best to conclude by reviewing its structure and protecting it against possible misinterpretations. I began by 
sketching the dispute - even within Simmel's own mind - over the question whether his early paper on "the relationship between the theory of selection and epistemology" expressed views best categorized as "pragmatist." Subsequently I summarized the key thought of this paper, and how its New Idea lived on in Simmel's oeuvre all the way to texts written towards the end of his life. I then turned to comparing Simmel's New Idea with some central threads in the writings of the three classical American pragmatists, Peirce, James and Dewey. Like his American contemporaries, Simmel was hostile towards traditional forms of the correspondence theory of truth; emphasized the link between truth and satisfaction; and opposed received forms of dualism. Intellectually, Simmel's closest counterpart on the other side of the Atlantic turned out to be Dewey, especially since both put the theory of evolution front and center in their philosophical efforts. Still, some of Dewey's uses of Darwin were more sophisticated and more naturalistic than Simmel's.

Was Simmel a pragmatist then? Yes and no. If by "pragmatist" one means a thinker whose work is, in important respects, similar to such paradigmatic pragmatist thinkers as Peirce, James or Dewey, then the answer must certainly be "yes." I think the above evidence is telling in this respect. And yet, there is also a consideration that might pull one to opt for a "no." Simmel's oeuvre is very wide-ranging, unsystematic - at least by the German standards of his time - and shaped by intellectual engagements with an unusually broad group of philosophers, natural scientists, historians and artists: from Meister Eckhart to Spinoza, Kant to Rickert, von Helmholtz to Dilthey, Marx to Schmoller, Schopenhauer to Nietzsche, Lazarus to Lamprecht, Michelangelo and Rembrandt to Rodin, Goethe to George, Durkheim to Weber. The men on this list were of much greater importance to Simmel's work than any of the American or European pragmatists of his time. And this speaks against labelling Simmel a pragmatist.

Finally, almost needless to say, the topics discussed in this paper do not exhaust the points of contact between Simmel and the pragmatist traditions. One could also compare and contract...

(a) the respective critical receptions of Comte, Darwin, Spencer, Kant, Hegel, Nietzsche or Bergson;

(b) the re-conceptualizing of experience so that it includes values and feelings;

(c) the focus on interest-, value-, memory-, or culture-ladenness of cognition and concepts;

(d) the re-interpretations of apriori principles as merely "regulative";

(e) the emphasis upon community and the "social self";

(f) and the book-length discussions of religious experience.

But these are issues for future work.

\section{BIBLIOGRAPHY}

BURKS Arthur W., (1997), "Logic, Learning, and Creativity in Evolution," in Nathan Houser (ed.), Studies in the Logic of Charles Sanders Peirce, Bloomington, Indiana University Press, 497-534. 
CAPPS John, (2019), “The Pragmatic Theory of Truth," Stanford Encyclopedia of Philosophy. Accessed Juni 10th, 2019.

DEWEY John, (1909), Ethics, New York, Henry Holt and Company. (Amazon Kindle Edition, numbers refer to Kindle locations.)

DEWEY John, (1925), Experience and Nature, Mccutchen Press, Kindle edition.

DEWEY John, (1938), Logic: The Theory of Inquiry, New York, Henry Holt.

DEWEY John, (1941), “Propositions, Warranted Assertibility, and Truth,” The Journal of Philosophy, $38,169-86$.

DEWEY John, (1972 [1898]), “Evolution and Ethics," in Early Works of John Dewey, 1882-1898, vol. 5, ed. by Jo Ann Boydston, Carbondale and Edwardsville, Southern Illinois University Press, 34-54.

DEWEY John, (1997 [1909]), “The Influence of Darwinism on Philosophy," in Id., The Influence of Darwin on Philosophy and other Essays, Amherst, Prometheus Books, 1-19.

DEWEY John, (2008 [1911]), “The Problem of Truth,” in John Dewey: The Middle Works, vol. 6, ed. by Jo Ann Boydston, Carbondale and Edwardsville, Southern Illinois University Press, 12-68.

ELSENHANS Theodor (ed.), (1909), Bericht über den III. Internationalen Kongress für Philosophie zu Heidelberg, 1. Bis 5. September 1908, Heidelberg, Winter.

EUCKEN Rudolf, (1890), Die Lebensanschauungen der großen Denker: Eine Entwickelungsgeschichte des Lebensproblems der Menschheit von Plato bis zur Gegenwart, Leipzig, Veit \& Co.

FRISCHEISEN-KÖHLER Max, (1920), “Georg-Simmel,” Kantstudien, 24, 1-51.

GESSNER Wilfried, (2003), Der Schatz im Acker: Georg Simmels Philosophie der Kultur, Göttingen, Velbrück.

HELLE Horst, (1988), Soziologie und Erkenntnistheorie bei Georg Simmel, Darmstadt, Wissenschaftliche Buchgesellschaft.

HELMHOLTZ Hermann von, (1867), Handbuch der physiologischen Optik, Leipzig, Voss.

JAMES William, (1907), Pragmatism: A New Name for Some Old Ways of Thinking, Amazon Kindle Edition. (Numbers refer to Kindle "locations" since no page numbers are provided in this edition.)

JAMES William, (1909), The Meaning of Truth, Amazon Kindle Edition.

JAMES William, (1918), The Principles of Psychology, Pantianos Classics, eBook Edition.

JERUSALEM Wilhelm, (1913), “Zur Weiterentwicklung des Pragmatismus,” Deutsche Literaturzeitung, 34, 3205-26.

KÖHNKE Klaus Christian, (1996), Der junge Simmel - in Theoriebeziehungen und sozialen Bewegungen, Frankfurt a. M., Suhrkamp.

MEAD George Herbert, (1901), "Review of Philosophie des Geldes," Journal of Political Economy, 9, 616-9.

MISAK Cheryl, (2013), The American Pragmatists, Oxford, Oxford University Press. PEIRCE Charles Sanders, (1935 [1902]), “Truth and Falsity and Error: Logical," in Collected Papers of Charles Sanders Peirce, vol. 5, ed. by Charles Hartshorne \& Paul Weiss, Cambridge, M.A., Harvard University Press, 565-573. 
PEIRCE Charles Sanders, (1986 [1878]), "How to Make Our Ideas Clear," in Writings of Charles S. Peirce: A Chronological Edition (Volume 3: 1872-1878), ed. by Christian Kloesel et al., Bloomington and Indianapolis, Indiana University Press, 257-76.

PEIRCE Charles Sanders, (1992 [1893]), “Evolutionary Love,” in The Essential Peirce, Selected Philosophical Writings, vol. 1 (1867-1893), ed. by Nathan Houser \& Christian Kloesel, Bloomington and Indianapolis, Indiana University Press, 352-71.

PEIRCE Charles Sanders, (1998 [1906]), “The Basis of Pragmaticism in the Normative Sciences," in The Essential Peirce, Selected Philosophical Writings, vol. 2 (1893-1913), ed. by the Peirce Edition Project, Nathan Houser et al., Bloomington and Indianapolis, Indiana University Press, 371-97.

PEIRCE Charles Sanders, (1998 [1908]), “A Neglected Argument for the Reality of God," in The Essential Peirce, Selected Philosophical Writings, vol. 2 (1893-1913), ed. by the Peirce Edition Project, Nathan Houser et al., Bloomington and Indianapolis, Indiana University Press, 434-50.

PERRY Ralph Barton, (1935), The Thought and Character of William James, as Revealed in Unpublished Correspondence and Notes, Together with his Published Writings, Westpoint, Conn., Greenwood Press. PRUS Robert C., (1996), Symbolic Interaction and Ethnographic Research, Albany, N.Y., State University of New York Press.

SIMMEL Georg, (1885), “Über eine Beziehung der Selectionslehre zur Erkenntnistheorie,” in Id. (1992), Aufsätze und Abhandlungen 1894-1900 (Simmel Gesamtausgabe 5), ed. by Heinz-Jürgen Dahme \& David P. Frisby, Frankfurt a. M., Suhrkamp, 62-75. English translation in Martin A. Coleman (2002), "Taking Simmel Seriously in Evolutionary Epistemology," Studies in History and Philosophy of Science, Part A, 33, 55-74. Page references are to the English translation.

SIMMEL Georg, (1914), “Henri Bergson,” in Aufsätze und Abhandlungen 1909-1918. Band II (Simmel Gesamtausgabe 13), ed. by Klaus Latzel, Frankfurt a. M., Suhrkamp, 53-69.

SIMMEL Georg, (1989 [1900]), Philosophie des Geldes (Simmel Gesamtausgabe 6), ed. by David P. Frisby \& Klaus Christian Köhnke, Frankfurt a. M., Suhrkamp.

SIMMEL Georg, (1997 [1904]), Kant. Die Probleme der Geschichtsphilosophie (Simmel, Gesamtausgabe 9), ed. by Guy Oakes \& Kurt Röttgers, Frankfurt a. M., Suhrkamp.

SIMMEL Georg, (1999 [1882]), "Psychologische und ethnologische Studien über Musik," in Id., Das Wesen der Materie nach Kant's Physischer Monadologie. Abhandlungen 1882-1884. Rezensionen 1883-1901 Simmel Gesamtausgabe 1), ed. by Klaus Christian Köhnke, Frankfurt a. M., Suhrkamp, 45-90.

SIMMEL Georg, (1999 [1918a]), "Der Konflikt der modernen Kultur," in Der Krieg und die geistigen Entscheidungen, Grundfragen der Soziologie, Vom Wesen des historischen Verstehens, Der Konflikt der modernen Kultur, Lebensanschauung (Simmel Gesamtausgabe 16), ed. by Gregor Fitzi \& Otthein Rammstedt, Frankfurt a. M., Suhrkamp, 181-207.

SIMMEL Georg, (1999 [1918b]), "Lebensanschauung," in Der Krieg und die geistigen Entscheidungen, Grundfragen der Soziologie, Vom Wesen des historischen Verstehens, Der Konflikt der modernen Kultur, Lebensanschauung (Simmel Gesamtausgabe 16), ed. by Gregor Fitzi \& Otthein Rammstedt, Frankfurt a. M., Suhrkamp, 209-425.

SIMMEL Georg, (2000), Das Wesen der Materie nach Kant's Physischer Monadologie, Anhandlungen 1882-1884, Renzensionen 1883-1901 (Simmel Gesamtausgabe 1), ed. by Klaus Christian Köhnke \& Otthein Rammstedt, Frankfurt a. M., Suhrkamp. 
SIMMEL Georg, (2003 [1913]), Goethe, Deutschlands innere Wandlung, Das Problem der historischen Zeit, Rembrandt (Simmel Gesamtausgabe 15), ed. by Uta Kösser, Hans-Martin Kruckis \& Otthein Rammstedt, Frankfurt a. M., Suhrkamp.

SIMMEL Georg, (2004), Postume Veröffentlichungen. Schulpädagogik (Simmel Gesamtausgabe 21), ed. by Torge Karlsruhen \& Otthein Rammstedt, Frankfurt a. M., Suhrkamp.

SIMMEL Georg, (2008), Briefe 1880-1911 (Simmel Gesamtausgabe 22), ed. by Klaus Christian Köhnke, Frankfurt a. M., Suhrkamp.

SIMMEL Georg, (2012), Kolleghefte und Mitschriften (Simmel Gesamtausgabe 21), ed. by Angela Rammstedt \& Cecile Rol, Frankfurt a. M., Suhrkamp.

SIMMEL Georg, (2016), Nachträge, Dokumente, Gesamtbibliographie, Übersichten, Indices (Simmel

Gesamtausgabe 24), ed. by Otthein Rammstedt, Angela Rammstedt \& Erwin Schullerus, Frankfurt a. M., Suhrkamp.

WINDELBAND Wilhelm, (1875), "Die Erkenntnislehre unter dem völkerpsychologischen Gesichtspunkte," Zeitschrift für Völkerpsychologie und Sprachwissenschaft, 8, 166-78.

\section{NOTES}

1. Simmel wrote extensively about Darwin already in the early 1880s (Simmel 1999 [1882]). Although he rarely mentions Spencer by name, Spencerian themes are prominent in the young Simmel (Köhnke 1996: 64-8). Although Lange is never mentioned in Simmel's published writings, Köhnke seems to me to be right to diagnose an influence (Köhnke 1996: 103). Windelband (1875) sketched a psychologistic theory of logic in the vicinity of Simmel's New Idea. Simmel repeatedly contributed to the same journal, the Zeitschrift für Völkerpsychologie und Sprachwissenschaft, and thus it is likely that he was familiar with Windelband's proposal.

\section{ABSTRACTS}

This paper offers some brief reflections on pragmatist themes in Georg Simmel's philosophy. \$1 presents a number of assessments - by Simmel's contemporaries, by later interpreters, and by Simmel himself - concerning his proximity to pragmatism. $\$ 2$ offers a reconstruction of Simmel's 1885-paper "The Relationship between the Theory of Selection and Epistemology," focusing in particular on what the argument owed to von Helmholtz. It was this paper first and foremost that suggested to many that Simmel was close to pragmatism. §§3-5 follow the development of the core idea of the 1885-paper in Simmel's subsequent writings. §§6-8 compare and contrasts Simmel's views on evolution and truth with the positions of Peirce, James, and Dewey. §9 returns to the overall question whether Simmel was a pragmatist and offers an irenic answer. 


\section{AUTHOR}

MARTIN KUSCH

Universität Wien

martin.kusch[at]univie.ac.at 